\title{
KINERJA PORTOFOLIO SAHAM BERDASARKAN STRATEGI INVESTASI MOMENTUM PADA INDEKS KOMPAS100
}

\author{
Putu Riska Yunita Srinandari ${ }^{1}$ \\ Ni Luh Putu Wiagustini ${ }^{2}$ \\ ${ }^{1,2}$ Fakultas Ekonomi dan Bisnis Universitas Udayana (Unud), Bali, Indonesia \\ email: riskasrinandari@gmail.com
}

\begin{abstract}
ABSTRAK
Tujuan penelitian ini adalah untuk mengetahui kinerja portofolio saham dengan menggunakan strategi investasi momentum pada indeks Kompas100. Ruang lingkup wilayah penelitian ini adalah perusahaan-perusahaan yang tergabung dalam Indeks Kompas100 yang terdaftar dalam Bursa Efek Indonesia periode 2012-2017. Jumlah sampel yang digunakan yaitu sebanyak 53 sampel. Metode pengumpulan data dilakukan melalui observasi nonparticipant dan menggunakan teknik analisis uji beda dua rata-rata. Berdasarkan hasil analisis data ditemukan bahwa hasil uji beda dua rata-rata Indeks Sharpe pada portofolio winner mendapatkan hasil yang tidak signifikan dan portofolio loser mendapatkan hasil yang signifikan. Hal ini membuat tidak terjadinya momentum melainkan adanya strategi kontrarian, dimana portofolio loser yang diukur dengan Indeks Sharpe mengalami penurunan selama periode kepemilikan 3, 6, 12 bulan secara signifikan dan membuat portofolio loser menderita kerugian berkepanjangan. Hasil penelitian ini mencerminkan bahwa strategi kontrarian merupakan strategi yang digunakan investor untuk mengharapkan terjadinya pembalikan terhadap return saham pada jangka waktu tertentu, yaitu tingkat return yang awalnya positif atau negatif diharapkan mengalami pembalikan pada jangka waktu tertentu. Kata Kunci: kinerja portofolio saham, strategi investasi momentum, indeks Kompas100.
\end{abstract}

\begin{abstract}
The purpose of this study was to determine the performance of the stock portfolio using the momentum investment strategy on the Kompas 100 index. The scope of this research area are companies incorporated in the Kompas 100 Index listed in the Indonesia Stock Exchange for the period 2012-2017. The number of samples used was 53 samples. The method of data collection is done through non-participant observation and using two different test analysis techniques on average. Based on the results of data analysis it was found that the results of the two different test averages of Sharpe Index on the winner's portfolio get insignificant results and the loser portfolio gets significant results. This made no momentum but a contrarian strategy, where the loser portfolio measured by the Sharpe Index significantly decreased during the ownership period of 3, 6, 12 months and made the loser portfolio suffer prolonged losses. The results of this study reflect that contrarian strategy is a strategy used by investors to expect a reversal of stock returns at a certain time period, namely the rate of return that is initially positive or negative is expected to experience a reversal in a certain period of time.
\end{abstract}

Keywords: stock portfolio performance, momentum investment strategy, Kompas 100 index. 


\section{PENDAHULUAN}

Investor pada dasarnya akan menempuh beberapa strategi untuk berinvestasi guna mendapatkan return yang maksimal tanpa melupakan faktor risiko yang harus dihadapi. Return merupakan keuntungan investor atas investasi yang telah dilakukan. Salah satu strategi yang akan digunakan oleh investor untuk berinvestasi adalah membentuk portofolio saham. Tujuan investor menggunakan portofolio untuk berinvestasi pada dasarnya untuk mengurangi risiko. Portofolio merupakan serangkaian kombinasi beberapa aktiva yang diinvestasikan dan dipegang oleh invesr, baik perorangan maupun lembaga (Wiagustini, 2008).

Investor dalam melakukan strategi portofolio terlebih dahulu harus membentuk dua jenis portofolio saham yaitu portofolio saham winner dan portofolio saham loser. Portofolio saham winner adalah kelompok saham-saham yang memiliki return positif, sedangkan portofolio saham loser adalah kelompok saham-saham yang memiliki return negatif. Bildik \& Gulay (2001) menjelaskan bahwa para akademisi dan praktisi manajemen keuangan sudah mengenal strategi investasi saham yang dapat digunakan investor untuk membentuk portofolio saham, selanjutnya pengujian dilakukan di berbagai pasar modal, dengan kesimpulan yang kontroversial yaitu reversal return dan continuation return.

Strategi investasi yang menghasilkan reversal return disebut dengan strategi kontrarian, sedangkan strategi investasi yang menghasilkan continuation return disebut dengan strategi investasi momentum. Strategi investasi kontrarian merupakan strategi yang digunakan investor untuk mengharapkan terjadinya pembalikan terhadap return saham pada jangka waktu tertentu, yaitu tingkat return yang awalnya positif atau negatif diharapkan mengalami pembalikan pada jangka waktu tertentu.

Strategi kontrarian sangat berlawanan dengan strategi investasi momentum, dimana strategi investasi momentum merupakan strategi investasi yang mengharapkan continuous return, yakni saham yang returnnya positif diharapkan akan terus positif sedangkan saham yang returnnya negatif akan terus negatif hingga jangka waktu tertentu.

Kontroversi kedua strategi tersebut sudah berlangsung sangat lama. Banyak penelitian yang sudah mengkaji strategi investasi dalam membentuk portofolio saham, khususnya strategi investasi kontrarian dan strategi investasi momentum. Masing-masing strategi tentunya memiliki pengaruh yang berbeda-beda terhadap kinerja portofolio saham di berbagai pasar modal, sehingga belum ditemukan hasil penelitian yang konsisten tentang pengaruh strategi investasi kontrarian maupun strategi investasi momentum.

Strategi investasi kontrarian pertama kali dipopulerkan oleh (DeBondt dan Thaler, 1985) dari sebuah penelitian yang dilakukannya di pasar modal Amerika Serikat. Mereka menemukan bahwa para investor hanya mengambil informasi sepenggal dan bereaksi terhadap munculnya informasi baru sehingga saham-saham yang pada mulanya memberikan tingkat return positif (winner) atau negatif (loser) akan mengalami pembalikan pada periode berikutnya.

Berbeda dengan strategi investasi momentum, investor dalam strategi momentum akan mencari momentum atau waktu yang tepat, pada saat perubahan harga yang terjadi bisa memberikan keuntungan bagi investor melalui tindakan 
menjual atau membeli saham (Tandelilin, 2010: 335). Strategi investasi momentum ini akan memanfaatkan pergerakan saham dengan harapan pergerakan tersebut akan terus berlanjut. Investor yang menggunakan strategi investasi momentum akan membeli saham pada saat harga sedang bergerak naik dengan harapan saham yang dibeli akan terus berlanjut di masa depan.

Investor akan menjual kembali saham-sahamnya bila dirasa momentum pergerakan naik telah melemah atau telah berhenti dan berbalik arah. Berdasarkan karakteristik strategi ini, para pengamat sering menjuluki strategi ini dengan julukan buy high sell higher (beli mahal, jual lebih mahal lagi).

Strategi investasi momentum dipopulerkan oleh Jegadeesh \& Titman (1993). Menggunakan data return saham individual di New York Stock Exchange (NYSE) dan American Stock Exchange (AMRX) dari tahun 1965-1989, mereka menemukan bahwa strategi investasi momentum biaya nihil dari pembelian saham pemenang (winner) dan penjualan saham pecundang (loser) menghasilkan abnormal return yang signifikan. Moskowitz dan Grinblatt (2007), meneliti strategi investasi momentum dalam portofolio berbasis industri. Mereka menemukan bahwa strategi investasi momentum yang dibentuk berdasarkan return saham industri ternyata lebih menguntungkan dari momentum return saham individual.

Forner \& Marhuenda (2003) melakukan penelitian di Spanish Stock Market menemukan abnormal return yang positif dengan menggunakan strategi momentum pada saat short term period. Penelitian strategi investasi momentum juga telah dilakukan oleh Rouwenhorst (1998) di pasar modal Eropa serta (Hurn \& Pavlov, 2003) di pasar modal Australia.

Hasil penelitian mereka menunjukkan bahwa strategi investasi momentum menguntungkan bila diterapkan di kedua pasar modal tersebut. Penelitian serupa juga ditemukan oleh Demir, Muthuswamy, \& Walter, 2004 di pasar modal Australia dengan membagi kedua sampel berdasarkan ukuran perusahaannya yang menemukan return secara berkelanjutan pada kedua sampel perusahaan besar dan perusahaan kecil.

Strategi investasi momentum menghasilkan abnormal return saham yang positif signifikan selama medium-horizon dan return saham yang tinggi selama dua tahun holding period ketika ranking period melebihi sembilan bulan, dengan membandingkan kinerja strategi momentum di tiga wilayah atau benua yang berbeda yaitu Eropa, Amerika, dan Asia-Pasifik, dimana kinerja terbaik ada di Amerika, penelitian ini ditemukan oleh Shan-Hu \& Chen (2011). Douagi \& Chaouachi (2011) melakukan penelitian di pasar modal Tunisia dan menemukan bahwa strategi momentum memberikan keuntungan yang signifikan hal ini didukung oleh temuan (Darusman, 2012).

Yunita (2012) melakukan penelitian mengenai overreaction di Indonesia, namun penelitiannya hanya dilakukan di perusahaan properti dan keuangan. Hasil penelitian menunjukkan bahwa anomali overreaction tidak terjadi pada perusahaan keuangan dan properti di Bursa Efek Indonesia, hal ini dikarenakan pola portofolio loser memiliki abnormal return negatif dan portofolio winner memiliki abnormal return positif, berarti penelitian tersebut sejalan dengan interpretasi dan strategi investasi momentum. melakukan penelitian mengenai profitabilitas strategi 
momentum saham industri di Bursa Efek Malaysia menyebutkan bahwa strategi momentum saham industri menguntungkan di Bursa Efek Malaysia.

Ada beberapa penelitian yang tidak setuju dengan interpretasi terhadap temuan empiris strategi momentum tersebut. Chan et al. (1996) dalam penelitiannya yang berjudul "Momentum Strategies" menunjukkan bahwa harga saham kurang bereaksi terhadap informasi yang terdapat informasi yang terdapat pada return saham yang lalu dan keuntungan perusahaan pada harga momentum. Bildik \& Gulay, (2001) di Istanbul Stock Exchange, serta Hameed \& Kusnasi (2002) melakukan penelitian di Pasar Modal Asia menemukan bahwa strategi investasi momentum tidak memberikan keuntungan yang signifikan.

Penelitian anomali overreaction di Indonesia oleh Sartono (2000) tidak hanya menguji hipotesis overreaction di Indonesia, hasil penelitiannya menyatakan bahwa gejala overreaction di Indonesia ditemukan pada portofolio saham besar dengan portofolio saham kecil. Rahmawati \& Suryani (2005) melakukan penelitian pada saham perusahaan manufaktur di Bursa Efek Indonesia, mereka menemukan bahwa terdapat indikasi reaksi berlebihan (overreaction) yang ditandai dengan portofolio saham loser mengungguli portofolio saham winner.

Wiksuana, (2009) menemukan bahwa portofolio winner-loser menghasilkan kinerja yang berbeda secara tidak signifikan berdasarkan strategi investasi momentum dan abnormal return portofolio winner periode formasi dengan periode pengujian cenderung negatif dan signifikan, sedangkan abnormal return portofolio loser periode formasi dengan periode pengujian cenderung positif dan signifikan untuk berbagai kelompok portofolio saham.

Gunarsa \& Ekayani (2011) menemukan adanya kecenderungan anomali winner-loser pada saham industri manufaktur di pasar modal Indonesia. Mereka menemukan yang pada mulanya memberikan return positif atau return negatif mengalami pembalikan pada akhir periode pengujian. Suarmanayasa dan Susila (2012) melakukan penelitian pada saham industri di pasar modal Indonesia, dan mereka menemukan adanya kecenderungan anomali winner dan loser dengan ratarata abnormal return portofolio winner sebanyak 27 observasi periode pengujian yang menunjukkan sebagian besar saham winner mengalami pembalikan return rata-rata ke arah negatif.

Henker (2012) melakukan penelitian dan menemukan bahwa strategi momentum tidak mendapatkan return yang signifikan selama periode penelitian. Mansouri, Tehrani, \& Ansari (2012) melakukan penelitian di Tehran Stock Exchange yang menemukan bahwa strategi momentum itu tidak menguntungkan dalam semua periode hal ini juga didukung oleh penelitian Saputro \& Badjra (2016).

Penelitian (Swandewi dan Mertha, 2013) menemukan bahwa terdapat perbedaan yang signifikan antara portofolio winner-loser saham industri manufaktur di pasar modal Indonesia selama 4 tahun, dengan rata-rata abnormal return portofolio winner sebanyak tujuh observasi periode pengujian yang memperlihatkan bahwa hanya sebagian kecil yang memperlihatkan return yang tetap positif dan sebagian besar portofolio saham winner mengalami pembalikan return ke arah negatif. Harianto (2008) mencoba menguji efektivitas strategi investasi momentum dalam menghasilkan abnormal return di pasar saham. Hasil 
empiris menunjukkan bahwa penggunaan strategi investasi momentum di pasar saham Indonesia ternyata tidak efektif memberikan abnormal return positif yang signifikan bagi investor.

Berdasarkan beberapa hasil penelitian yang sudah dilakukan terdahulu, maka dapat dikatakan strategi investasi momentum menerapkan isu yang masih kontroversial. Fenomena ini sangat menarik dan perlu dilakukan penelitian empiris tentang subyek ini, untuk bisa memperoleh bukti empiris bahwa strategi investasi momentum merupakan strategi yang sangat layak digunakan oleh para investor dan manajer investasi dalam penerapannya di pasar modal Indonesia. Penelitian ini juga dilakukan untuk mengetahui kinerja portofolio saham yang akan dihasilkan dengan menggunakan strategi investasi momentum pada Indeks Kompas 100.

Penelitian ini lebih melihat pada sisi strategi momentum, karena strategi ini sangat populer digunakan oleh investor. Investor tentunya akan memilih untuk membeli saham-saham yang memiliki kinerja baik dan menjual saham-saham yang memiliki kinerja buruk. Hal tersebut sejalan dengan penggunaan Indeks Kompas100 sebagai ruang lingkup penelitian ini. Susanti dan Syahyunan (2013) menyatakan bahwa Indeks Kompas100 merupakan suatu indeks saham dari 100 saham perusahaan publik yang diperdagangkan di Bursa Efek Indonesia (BEI).

Indeks Kompas 100 secara resmi diterbitkan oleh Bursa Efek Indonesia bekerjasama dengan koran Kompas pada hari Jumat, 10 Agustus 2007. Sahamsaham yang terpilih dan dimasukkan dalam Indeks Kompas100 selain memiliki likuiditas yang tinggi, serta nilai kapitalisasi pasar yang besar, juga merupakan saham-saham yang memiliki fundamental dan kinerja yang baik. Saham-saham yang masuk dalam Indeks Kompas 100 diperkirakan mewakili sekitar 70-80\% dari total nilai kapitalisasi pasar seluruh saham yang tercatat di Bursa Efek Indonesia (BEI), maka dengan demikian para investor bisa melihat kecenderungan arah pergerakan indeks dengan mengamati pergerakan Indeks Kompas100 (Kartajaya, 2009: 1).

Pengukuran kinerja portofolio saham dalam penelitian ini menggunakan abnormal return sebagaimana yang dilakukan dalam penelitian-penelitian sebelumnya, penelitian ini juga menggunakan risk-adjusted return. Abnormal return merupakan perbedaan antara return portofolio sebenarnya dengan return portofolio ekspektasi (return normal), sedangkan risk-adjusted return merupakan return per unit risiko yang diukur menggunakan indeks Sharpe, indeks Treynor, dan indeks Jensen. Tetapi, penelitian ini hanya menggunakan indeks Sharpe, karena indeks Sharpe tepat digunakan untuk mengukur portofolio saham yang kurang terdiversifikasi dengan baik.

Periode yang akan digunakan untuk mengukur kinerja portofolio saham dalam penelitian ini yaitu periode formasi 12 bulan. Penggunaan 12 bulan atau setahun pada periode formasi, karena pada umumnya para investor melihat datadata historis pada tahun sebelumnya yang dianggap representatif untuk dijadikan sebagai pertimbangan dalam membentuk portofolio saham. Periode kepemilikan selanjutnya sebagai pengujian adalah 3,6 , dan 12 bulan berikutnya, alasannya karena laporan keuangan di Bursa Efek Indonesia (BEI) diterbitkan setiap triwulan.

Periode tersebut juga dapat memberikan informasi yang lebih mendalam kepada para investor tentang periode waktu membeli, menahan, dan menjual 
saham. Periode formasi adalah periode pembentukan portofolio saham winner dan portofolio saham loser, sedangkan periode kepemilikan selanjutnya adalah periode pengujian (observasi) portofolio saham winner dan portofolio saham loser yang sebelumnya telah ditentukan pada periode formasi. Periode penelitian ini adalah dari tahun 2012 hingga tahun 2017, alasan penelitian ini dilakukan dari tahun 2012 hingga tahun 2017 adalah ingin mengetahui bagaimana kinerja portofolio pada indeks Kompas 100 terkini.

Teori investasi lebih menganjurkan kepada para investor untuk membentuk portofolio dalam berinvestasi saham. Portofolio keuangan dapat diartikan sebagai investasi dalam berbagai instrumen keuangan yang bias diperdagangkan di Bursa Efek dan Pasar Uang, dengan tujuan untuk menyebarkan sumber perolehan return dan kemungkinan risiko. Instrument keuangan yang dimaksud yaitu meliputi saham, obligasi, valuta asing, deposito, indeks harga saham dan produk derivative lainnya.

Beberapa pakar keuangan memberi saran bahwa investasi jangan hanya dilakukan pada satu saham saja melainkan di beberapa saham dan berbagai industri. Ada dua strategi yang dapat dilakukan investor untuk membentuk portofolio saham, yaitu strategi portofolio pasif dan strategi portofolio aktif. Strategi portofolio pasif meliputi tindakan investor yang cenderung pasif dalam melakukan investasi pada saham dan investor hanya melihat pergerakan sahamnya pada indeks pasar.

Strategi portofolio pasif memiliki tujuan yaitu untuk mengikuti kinerja indeks pasar sedekat mungkin. Dalam strategi ini investor tidak secara aktif mencari informasi maupun melakukan jual beli saham yang bias menghasilkan abnormal return. Para investor yang menggunakan strategi ini biasanya akan percaya bahwa harga pasar yang terjadi adalah harga yang mencerminkan nilai intrinsic saham tersebut.

Strategi portofolio aktif, para investor akan secara aktif melakukan pemilihan dan jual beli saham, mencari informasi, mengikuti waktu dan pergerakan harga saham serta berbagai tindakan aktif lainnya untuk menghasilkan abnormal return. Strategi aktif memiliki tujuan untuk mencapai return portofolio saham yang melebihi return portofolio saham yang diperoleh melalui strategi pasif. Dalam startegi ini untuk membentuk portofolio saham bias menggunakan dua pendekatan dalam analisis saham, yaitu pendekatan analisis fundamental dan pendekatan analisis teknikal.

Pendekatan analisi fundamental yaitu pendekatan yang digunakan untuk menganalisis saham berdasarkan data-data perusahaan, seperti earning, dividen, penjualan, dan lain sebagainya. Sedangkan pendekatan analisis teknikal yaitu pendekatan yang digunakan untuk mencari pola pergerakan harga saham yang bias dipakai untuk meramalkan pergerakan harga saham di kemudian hari.

Tiga strategi yang digunakan para investor dalam menjalankan strategi portofolio aktif adalah pemilihan saham, rotasi sector, dan strategi momentum harga. Para investor dalam strategi pemilihan saham secara aktif melakukan analisis dan pemilihan saham-saham terbaik, yaitu saham-saham yang memberikan hubungan tingkat return-risiko yang terbaik dibandingkan dengan alternatif lainnya. Sedangkan rotasi sector dilakukan oleh para investor yang berinvestasi pada sahm-saham di dalam negeri saja. Para investor biasanya akan membeli 
saham-saham pada suatu industry tertentu yang akan diperkirakan mengalami peningkatan nilai melebihi return pasar.

Strategi investasi momentum membuat para investor akan berasumsi bahwa apa yang terjadi di masa lalu cenderung akan terulang lagi di masa mendatang. Investor mengasumsikan bahwa kemungkinan hasil yang terjadi pada saat ini akan sama atau muncul lagi pada masa depan (Sharpe et al., 1995). Investor momentum akan berusaha membeli saham yang harganya baru saja naik atau memiliki kinerja yang baik, atas dasar kepercayaan bahwa harga saham tersebut akan terus naik atau mengalami peningkatan. Saham-saham yang memiliki kinerja buruk akan dijual dengan kepercayaan bahwa saham-saham tersebut akan terus berada pada kinerja yang buruk.

Investor berdasarkan strategi investasi momentum ini akan membentuk portofolio saham dengan melakukan pembelian yang sebelumnya memiliki kinerja yang baik atau disebut dengan portofolio winner, sehingga portofolio winner tetap menghasilkan kinerja yang lebih tinggi dibandingkan portofolio loser pada periode mendatang dan tidak terdapat perbedaan yang signifikan antara kinerja portofolio saham winner pada periode formasi dengan periode kepemilikan selanjutnya.

Beberapa penelitian sebelumnya yang mendukung deskripsi teori strategi investasi momentum yang dijadikan sebagai acuan atau patakon untuk merumuskan hipotesis dalam penelitian ini, yaitu:

Rouwenhorst (1998) melakukan penelitian dengan menggunakan sampel 12 negara Eropa dari tahun 1980 sampai tahun 1995. Hasil penelitian tersebut menunjukkan strategi investasi momentum menguntungkan apabila diterapkan di pasar modal Eropa. Grundy \& Martin (2001), menguji strategi investasi momentum dengan jangka waktu yang lebih panjang, dan hasil penelitiannya menemukan bahwa strategi investasi momentum sudah menguntungkan di Amerika Serikat sejak tahun 1920-an. Former dan Joaquin Marhuenda (2003) melakukan penelitian di Spanish Stock Market menemukan abnormal return yang positif dengan menggunakan strategi momentum pada saat short term period. Penelitian yang serupa ditemukan (Demir et al., 2004) di pasar modal Australia.

Najmudin, (2009) melakukan penelitian dan menemukan bahwa terdapat anomali winner-loser di Bursa Efek Indonesia dalam jangka pendek yang berupa terjadinya investor underraction. Baik saham winner ataupun saham loser masingmasing bergerak dengan tidak berganti posisi sejak periode pembentukan sampai dengan periode pengujian. Shan-Hu \& Chen (2011) melakukan penelitian dan menemukan bahwa strategi investasi momentum menghasilkan abnormal return saham yang positif selama medium-horizon dan return saham yang tinggi selama dua tahun holding period ketika ranking period melebihi sembilan bulan.

Douagi \& Chaouachi (2011) melakukan penelitian di pasar modal Tunisia menemukan bahwa strategi investasi momentum memberikan keuntungan signifikan. Pasaribu (2011) melakukan penelitian untuk mengetahui adanya reaksi berlebih di Indonesia melalui harga saham perusahan LQ-45 dengan judul "Anomali Overreaction di Bursa Efek Indonesia: Penelitian Saham LQ-45". Hasil penelitian tersebut menyatakan bahwa tidak ada reaksi berlebih di Indonesia, maka secara teoritis strategi investasi momentum bisa diterapkan investor untuk melakukan investasi. 
Yunita (2012) juga melakukan penelitian mengenai overreaction di Indonesia, namum penelitiannya hanya dilakukan pada perusahaan keuangan dan properti. Hasil penelitiannya menunjukkan bahwa anomali overreaction tidak terjadi pada perusahaan keuangan dan properti di Bursa Efek Indonesia, karena pola portofolio winner memiliki abnormal return positif sedangkan portofolio loser memiliki abnormal return yang negatif. Elias, Hanis, Azmi, \& Kamil (2014) di Bursa Efek Malaysia mengenai profitabilitas strategi investasi momentum saham indutri, dan penelitian ini menemukan bahwa strategi investasi momentum saham industri menguntungkan di Bursa Efek Malaysia.

Berdasarkan teori dan hasil penelitian sebelumnya yang telah dipaparkan di atas, maka hipotesis yang dapat diajukan dalam penelitian ini sebagai berikut:

$\mathrm{H}_{1}$ : Terdapat perbedaan signifikan antara kinerja portofolio saham winner pada periode formasi dengan kinerja portofolio saham winner pada periode kepemilikan selanjutnya.

$\mathrm{H}_{2}$ : Terdapat perbedaan signifikan antara kinerja portofolio saham loser pada periode formasi dengan kinerja portofolio saham loser pada periode kepemilikan selanjutnya.

\section{METODE PENELITIAN}

Penelitian ini akan dilakukan di perusahaan-perusahaan Indeks Kompas100 yang sahamnya tercatat di Bursa Efek Indonesia (BEI), dan aktif diperdagangkan selama periode Januari 2012 sampai dengan Desember 2017. Obyek penelitian ini adalah kinerja portofolio saham dengan menggunakan strategi investasi momentum pada perusahaan yang termasuk di dalam Indeks Kompas100 yang sahamnya tercatat di Bursa Efek Indonesia.

Berdasarkan model disesuaikan pasar (market-adjusted model), pengukuran abnormal return portofolio saham winner-loser dilakukan dengan cara sebagai berikut:

Menghitung abnormal return masing-masing saham yang akan membentuk portofolio saham winner-loser dengan menggunakan rumus (Tandelilin, 2010: 225)

$\mathrm{AR}_{\mathrm{t}}=\mathrm{R}_{\mathrm{t}}-\mathrm{R}_{\mathrm{Mt}}$

Keterangan:

$\mathrm{AR}_{\mathrm{t}}=$ Abnormal return saham-saham yang membentuk portofolio saham winner-loser

$\mathrm{R}_{\mathrm{t}} \quad=$ Actual return saham-saham yang membentuk portofolio winner-loser saham yang dihitung dari akumulasi perubahan harga saham relatif per bulan.

$\mathrm{R}_{\mathrm{Mt}}=$ Market return yang dihitung dari akumulasi perubahan IHSG relatif per bulan.

Menghitung rata-rata abnormal return portofolio winner-loser, dengan rumus (Hartono, 2013: 622) 
$\mathrm{AAR}_{\mathrm{t}}=\sum_{\mathrm{i}=\mathrm{l}}^{\mathrm{n}} \mathrm{AR}_{\mathrm{t}} / \mathrm{n}$

Keterangan:

$\mathrm{AAR}_{\mathrm{t}}=$ Rata-rata abnormal return portofolio winner-loser .

$\mathrm{AR}_{\mathrm{t}}=$ Abnormal return saham-saham yang membentuk portofolio winner loser saham.

$\mathrm{n} \quad=$ Jumlah saham yang membentuk portofolio winner-loser.

Menghitung kumulatif abnormal return portofolio winner-loser, dengan rumus (Hartono, 2013:625):

$\mathrm{CAR}_{\mathrm{t}}=\sum_{\mathrm{t}=1}^{\mathrm{n}} \mathrm{AAR}_{\mathrm{t}}$

Keterangan:

$\mathrm{CAR}_{\mathrm{t}}=$ Kumulatif abnormal return portofolio winner-loser.

$\mathrm{AAR}_{\mathrm{t}}=$ Rata-rata abnormal return portofolio winner-loser.

$\mathrm{n} \quad=$ Jumlah observasi.

Menghitung rata-rata kumulatif abnormal return portofolio winner-loser dengan rumus (Wiksuana, 2009):

$\mathrm{ACAR}_{\mathrm{t}}=\mathrm{CAR}_{\mathrm{t}} / \mathrm{n}$

Keterangan:

ACARt $=$ Rata-rata kumulatif abnormal return portofolio winner-loser .

CARt $=$ Kumulatif abnormal return portofolio winner-loser .

$\mathrm{n} \quad=$ Jumlah observasi.

Risk-adjusted portofolio winner-loser adalah pengukuran kinerja portofolio yang sudah memasukkan faktor risiko, di dalam penelitian ini menggunakan indeks Sharpe portofolio saham winner dan loser berdasarkan strategi investasi momentum pada perusahaan-perusahaan yang termasuk di dalam Indeks Kompas100 selama periode 2012 sampai 2017. Indeks Sharpe digunakan untuk mengukur portofolio yang kurang terdiversifikasi dengan baik, sesuai dengan penelitian ini yang hanya menggunakan Indeks Kompas100.

Pengukuran indeks Sharpe portofolio winner-loser saham dilakukan dengan rumus (Tandelilin, 2010: 494)

$\mathrm{Sp}=\frac{\overline{\mathrm{R}_{\mathrm{P}}}-\overline{\mathrm{R}_{\mathrm{F}}}}{\sigma_{\mathrm{P}}}$

Keterangan:

$\widehat{S p}=$ Indeks Sharpe portofolio winner-loser.

$\mathrm{R}_{\mathrm{P}}=$ Rata-rata return portofolio winner-loser .

$\underline{\mathrm{R}}_{\mathrm{F}}=$ Rata-rata return bebas risiko yang dihitung dari rata-rata tingkat bunga SBI

$\sigma_{\mathrm{P}}=$ Standar deviasi return portofolio 
Populasi penelitian ini adalah seluruh perusahaan-perusahaan yang termasuk di dalam Indeks Kompas100 di Bursa Efek Indonesia dari tahun 2012 sampai dengan tahun 2017. Sampel merupakan himpunan objek dari pengamatan yang dipilih dari populasi yang memiliki karakteristik yang akan diselidiki dan dianggap bisa mewakili keseluruhan populasi. Sampel dalam penelitian ini diambil dengan menggunakan metode purposive sampling, yaitu peneliti sebelum mengambil sampel harus membuat kriteria-kriteria tertentu yang diinginkan dari sampel. Kriteria sampel dalam penelitian ini adalah saham-saham yang menerbitkan laporan tahunan dan terdaftar secara konsisten selama 5 tahun pada Indeks Kompas 100 di Bursa Efek Indonesia (BEI) periode 2012-2017. Jumlah sampel pada penelitian ini sebanyak 53 perusahaan.

Penelitian ini menggunakan sumber data sekunder. Data sekunder adalah sumber data yang didapat secara tidak langsung dengan menggunakan media perantara dan melalui kegiatan dokumentasi (didapatkan dan dicatat oleh pihak lain). Data tersebut dikumpulkan untuk periode Januari 2012 sampai desember 2017. Data harga saham digunakan untuk menghitung return saham, data tingkat bunga digunakan untuk menghitung return bebas risiko, dan data IHSG digunakan untuk menghitung return pasar.

Pengujian hipotesis penelitian dilakukan dengan menggunakan teknik analisis statistik uji beda dua rata-rata. Teknik analisis statistik uji beda dua ratarata ini digunakan untuk menguji signifikansi perbedaan kinerja portofolio saham winner-loser periode formasi dengan periode selanjutnya. Hasil pengujian ini dapat memberikan bukti empiris dalam bentuk penerapan strategi investasi saham di Bursa Efek Indonesia (BEI) dengan memanfaatkan karakteristik perusahaan dan dapat pula digunakan bagi pelaku pasar modal seperti investor yang menginginkan hasil (return) yang layak dari suatu investasi saham dan manajer investasi dalam melakukan analisis dan merumuskan kebijakan investasi saham yang lebih tepat dan menguntungkan di Bursa Efek Indonesia (BEI). Adapun rumus pengujian dengan menggunakan statistik uji beda dua rata-rata adalah sebagai berikut:

$t=\frac{\overline{X_{1}}-\overline{X_{2}}}{\sqrt{\frac{\left(n_{1}-1\right) S_{1}^{2}+\left(n_{2}-1\right) S_{2}^{2}\left(\frac{1}{n_{1}}+\frac{1}{n_{2}}\right)}{n_{1}+n_{2}-2}} .}$

Keterangan:

$\overline{X_{1}}=$ Rata-rata kinerja portofolio saham winner-loser periode formasi.

$\overline{X_{2}}=$ Rata-rata kinerja portofolio saham winner-loser periode selanjutnya.

$S_{1}=$ simpangan baku portofolio saham winner-loser periode formasi.

$S_{2}=$ simpangan baku portofolio saham winner-loser periode selanjutnya.

$n_{1}=$ jumlah sampel kinerja portofolio saham winner-loser periode formasi.

$n_{2}=$ jumlah sampel kinerja portofolio saham winner-loser periode selanjutnya.

\section{HASIL DAN PEMBAHASAN}

Indeks Kompas100 adalah suatu indeks saham dari 100 perusahaan publik yang diperdagangkan di Bursa Efek Indonesia. Indeks Kompas100 secara resmi 
diterbitkan oleh Bursa Efek Indonesia bekerjasama dengan Koran Kompas pada hari Jumat tanggal 10 Agustus 2007. Saham-saham yang terpilih untuk dimasukkan dalam Indeks Kompas100 ini selain memiliki likuiditas yang tinggi, serta nilai kapitalisasi pasar yang besar, juga merupakan saham-saham yang memiliki fundamental dan kinerja yang baik. Portofolio saham winner-loser periode formasi 12 bulan dengan periode kepemilikan 3 bulan selanjutnya selama tahun 2012-2017 meliputi 5 kali observasi. Observasi pertama dimulai dari periode formasi 12 bulan di tahun 2012 dengan periode kepemilikan 3 bulan selanjutnya, yaitu bulan JanuariMaret 2013. Observasi kedua yaitu pada periode formasi 12 bulan di tahun 2013 dengan periode kepemilikan 3 bulan selanjutnya, yaitu bulan Januari-Maret 2014.

Observasi ketiga yaitu pada periode formasi 12 bulan di tahun 2014 dengan periode kepemilikan 3 bulan selanjutnya, yaitu bulan Januari-Maret 2015 . Observasi keempat yaitu pada periode formasi 12 bulan di tahun 2015 dengan periode kepemilikan 3 bulan selanjutnya, yaitu bulan Januari-Maret 2016 . Observasi kelima yaitu pada periode formasi 12 bulan di tahun 2016 dengan periode kepemilikan 3 bulan selanjutnya yaitu bulan Januari-Maret 2017.

Portofolio saham winner-loser periode formasi 12 bulan dengan periode kepemilikan 6 bulan selanjutnya selama tahun 2012-2017 juga meliputi 5 kali observasi. Observasi pertama dimulai dari periode formasi 12 bulan di tahun 2012 dengan periode kepemilikan 6 bulan selanjutnya, yaitu bulan Januari-Juni 2013. Observasi kedua yaitu pada periode formasi 12 bulan di tahun 2013 dengan periode kepemilikan 6 bulan selanjutnya, yaitu bulan Januari-Juni 2014.

Observasi ketiga yaitu pada periode formasi 12 bulan di tahun 2014 dengan periode kepemilikan 6 bulan selanjutnya, yaitu bulan Januari-Juni 2015. Observasi keempat yaitu pada periode formasi 12 bulan di tahun 2015 dengan periode kepemilikan 6 bulan selanjutnya, yaitu bulan Januari-Juni 2016. Observasi kelima yaitu pada periode formasi 12 bulan di tahun 2016 dengan periode kepemilikan 6 bulan selanjutnya yaitu bulan Januari-Juni 2017.

Portofolio saham winner-loser periode formasi 12 bulan dengan periode kepemilikan 12 bulan selanjutnya selama tahun 2012-2017 juga meliputi 5 kali observasi. Observasi pertama dimulai dari periode formasi 12 bulan di tahun 2012 dengan periode kepemilikan 12 bulan selanjutnya, yaitu bulan Januari-Desember 2013. Observasi kedua yaitu pada periode formasi 12 bulan di tahun 2013 dengan periode kepemilikan 12 bulan selanjutnya, yaitu bulan Januari-Desember 2014.

Observasi ketiga yaitu pada periode formasi 12 bulan di tahun 2014 dengan periode kepemilikan 12 bulan selanjutnya, yaitu bulan Januari-Desember 2015 . Observasi keempat yaitu pada periode formasi 12 bulan di tahun 2015 dengan periode kepemilikan 12 bulan selanjutnya, yaitu bulan Januari-Desember 2016. Observasi kelima yaitu pada periode formasi 12 bulan di tahun 2016 dengan periode kepemilikan 12 bulan selanjutnya yaitu bulan Januari-Desember 2017.

Rincian data periode formasi pembentukan portofolio dan periode kepemilikan selanjutnya dapat dilihat pada Tabel 1.

Kinerja portofolio saham winner-loser periode formasi dengan periode kepemilikan selanjutnya diukur dengan abnormal return dan risk adjusted returns (Indeks Sharpe). 
Abnormal return portofolio winner-loser merupakan rata-rata kumulatif abnormal return portofolio winner dan portofolio loser berdasarkan strategi investasi momentum pada periode formasi 12 bulan dengan periode kepemilikan 3 , 6, 12 bulan selanjutnya periode 2012-2017.

Tabel 1.

Tabel Observasi Periode Formasi dan Periode Kepemilikan Portofolio Saham Winner-Loser Tahun 2012-2017

\begin{tabular}{ccccc}
\hline \multirow{2}{*}{ Observasi } & \multirow{2}{*}{ Periode Formasi } & \multicolumn{2}{c}{ Periode Kepemilikan Selanjutnya } \\
& & 3 Bulan & 6 Bulan & 12 Bulan \\
\hline \multirow{2}{*}{1} & Januari-Desember & Januari-Maret & Januari-Juni & Januari-Desember \\
& 2012 & 2013 & 2013 & 2013 \\
2 & Januari-Desember & Januari-Maret & Januari-Juni & Januari-Desember \\
& 2013 & 2014 & 2014 & 2014 \\
3 & Januari-Desember & Januari-Maret & Januari-Juni & Januari-Desember \\
& 2014 & 2015 & 2015 & 2015 \\
4 & Januari-Desember & Januari-Maret & Januari-Juni & Januari-Desember \\
& 2015 & 2016 & 2016 & 2016 \\
5 & Januari-Desember & Januari-Maret & Januari-Juni & Januari-Desember \\
& 2016 & 2017 & 2017 & 2017 \\
\hline
\end{tabular}

Sumber: data diolah, 2018

Berdasarkan statistik deskriptif, rata-rata kumulatif abnormal return portofolio winner periode formasi 12 bulan memiliki rata-rata kumulatif abnormal return terendah pada periode kepemilikan 12 bulan selanjutnya, yaitu sebesar 0,02000 dengan nilai minimum 0,190 dan nilai maksimum 0,150 serta standar deviasi sebesar 0,145258 , sedangkan rata-rata kumulatif abnormal return tertinggi portofolio winner adalah pada periode kepemilikan 3 bulan selanjutnya, yaitu sebesar 0,5420 dengan nilai minimum $-0,030$ dan nilai maksimum 0,240 serta standar deviasi sebesar 0,110875. Rata-rata kumulatif abnormal return portofolio loser periode formasi 12 bulan memiliki rata-rata kumulatif abnormal return terendah pada periode kepemilikan 3 bulan selanjutnya, yaitu sebesar 0,89800 dengan nilai minimum $-1,800$ dan nilai maksimum 0,500 serta standar deviasi sebesar 1,034418 sedangkan rata-rata kumulatif abnormal return tertinggi portofolio winner adalah pada periode kepemilikan 12 bulan selanjutnya,yaitu sebesar 0,73400 dengan nilai minimum -1,330 dan nilai maksimum 3,000 serta standar deviasi sebesar 1,875841 .

Hasil perhitungan rata-rata kumulatif abnormal return portofolio saham winner periode formasi 12 bulan dengan periode kepemilikan 3, 6, 12 bulan selanjutnya, menunjukkan bahwa rata-rata kumulatif abnormal return portofolio saham winner pada periode formasi 12 bulan mengalami kenaikan pada periode kepemilikan 3, 6, 12 bulan selanjutnya, dan dari kelima observasi yang telah dilakukan, menyatakan bahwa return mengalami pembalikan ke arah positif, seperti pada Tabel 2.

Hasil perhitungan rata-rata kumulatif abnormal return portofolio saham loser periode formasi 12 bulan dengan periode kepemilikan 3, 6, 12 bulan selanjutnya, menunjukkan bahwa rata-rata kumulatif abnormal return portofolio saham loser pada periode formasi 12 bulan mengalami penurunan pada periode kepemilikan 3 , 
6, 12 bulan selanjutnya, dan dari kelima observasi yang telah dilakukan, menyatakan bahwa return tetap negatif, seperti pada Tabel 3.

Tabel 2.

Rata-rata Kumulatif Abnormal Return Portofolio Winner Periode Formasi 12 Bulan dan Periode Kepemilikan 3, 6, dan 12 Bulan Tahun 2012-2017.

\begin{tabular}{cccccccc}
\hline \multirow{2}{*}{ Observasi } & Periode & \multicolumn{3}{c}{ Periode Kepemilikan } & \multicolumn{4}{c}{ Beda } \\
& Formasi & 3 bulan & 6 bulan & $\mathbf{1 2}$ bulan & $\mathbf{3}$ bulan & 6 bulan & 12 bulan \\
\hline 1 & 0,00 & 0,03 & $-0,15$ & $-0,15$ & $-0,03$ & 0,15 & 0,15 \\
2 & $-0,13$ & 0,06 & 0,05 & 0,06 & $-0,19$ & $-0,18$ & $-0,19$ \\
3 & 0,07 & $-0,17$ & $-0,09$ & $-0,04$ & 0,24 & 0,16 & 0,11 \\
4 & $-0,01$ & $-0,02$ & 0,04 & 0,05 & 0,01 & $-0,05$ & $-0,06$ \\
5 & 0,09 & 0,02 & $-0,01$ & $-0,02$ & 0,07 & 0,10 & 0,11 \\
CARt & 0,02 & $-0,08$ & $-0,16$ & $-0,10$ & 0,10 & 0,18 & 0,12 \\
ACARt & 0,00 & $-0,02$ & $-0,03$ & $-0,02$ & 0,02 & 0,04 & 0,02 \\
\hline
\end{tabular}

Sumber: Data diolah, 2018

Keterangan:

Beda $=$ selisih abnormal return portofolio winner periode formasi dengan periode kepemilikan selanjutnya

Tabel 3.

Rata-rata Kumulatif Abnormal Return Portofolio Loser Periode Formasi 12 Bulan dan Periode Kepemilikan 3, 6, dan 12 Bulan Tahun 2012-2017.

\begin{tabular}{cccccccc}
\hline \multirow{2}{*}{ Observasi } & Periode & \multicolumn{3}{c}{ Periode Kepemilikan } & \multicolumn{3}{c}{ Beda } \\
& Formasi & 3 bulan & 6 bulan & $\mathbf{1 2}$ bulan & 3 bulan & 6 bulan & 12 bulan \\
\hline 1 & $-0,05$ & $-0,05$ & $-0,21$ & $-0,16$ & 0,00 & 0,16 & 0,11 \\
2 & $-0,17$ & 0,07 & 0,05 & 0,04 & $-0,24$ & $-0,22$ & $-0,21$ \\
3 & 0,03 & $-0,20$ & $-0,09$ & $-0,04$ & 0,23 & 0,12 & 0,07 \\
4 & $-0,07$ & 0,08 & 0,10 & 0,07 & $-0,15$ & $-0,17$ & $-0,14$ \\
5 & 0,02 & $-0,02$ & $-0,01$ & $-0,02$ & 0,04 & 0,03 & 0,04 \\
CARt & $-0,24$ & $-0,12$ & $-0,16$ & $-0,11$ & $-0,12$ & $-0,08$ & $-0,13$ \\
ACARt & $-0,05$ & $-0,02$ & $-0,03$ & $-0,02$ & $-0,02$ & $-0,02$ & $-0,03$ \\
\hline
\end{tabular}

Sumber: Data diolah, 2018

Keterangan:

Beda $=$ selisih abnormal return portofolio winner periode formasi dengan periode kepemilikan selanjutnya

Berdasarkan statistik deskriptif, rata-rata Indeks Sharpe portofolio winner periode formasi 12 bulan dengan periode kepemilikan 3, 6, 12 bulan selanjutnya menunjukkan bahwa rata-rata Indeks Sharpe tertinggi terjadi pada periode kepemilikan 12 bulan selanjutnya, yaitu sebesar 0,73400 dengan nilai minimum 1,330 dan nilai maksimum 3,000 serta standar deviasi sebesar 1,875841, sedangkan rata-rata Indeks Sharpe terendah terjadi pada periode kepemilikan 3 bulan selanjutnya, yaitu sebesar 0,89800 dengan nilai minimum $-1,800$ dan nilai maksimum 0,500 serta standar deviasi sebesar 1,034418. Rata-rata Indeks Sharpe portofolio loser juga memiliki nilai tertinggi pada periode kepemilikan 12 bulan 
selanjutnya, yaiu sebesar $-3,05000$ dengan nilai minimum $-5,250$ dan nilai maksimum -1,000 serta standar deviasi 1,971674, sedangkan rata-rata Indeks Sharpe terendah terjadi pada periode kepemilikan 3 bulan selanjutnya, yaitu sebesar $-4,72800$ dengan nilai minimum $-6,440$ dan nilai maksimum $-1,800$ serta standar deviasi sebesar 1,930264 .

Tabel 4.

Rata-Rata Indeks Sharpe Portofolio Winner Periode Formasi 12 Bulan dengan Periode Kepemilikan 3, 6, 12 Bulan Tahun 2009-2014

\begin{tabular}{cccccccc}
\hline \multirow{2}{*}{ Observasi } & Periode & \multicolumn{3}{c}{ Periode Kepemilikan } & \multicolumn{3}{c}{ Beda } \\
& Formasi & 3 Bulan & 6 Bulan & 12 Bulan & 3 Bulan & 6 Bulan & 12 Bulan \\
\hline 1 & $-1,00$ & 0,25 & $-0,80$ & $-2,00$ & 1,25 & 0,20 & $-1,00$ \\
2 & $-2,00$ & $-0,20$ & $-1,00$ & $-1,00$ & 1,80 & 1,00 & 1,00 \\
3 & $-1,50$ & $-2,00$ & $-3,33$ & $-4,50$ & 0,50 & $-1,83$ & $-3,00$ \\
4 & $-3,00$ & $-1,20$ & $-1,00$ & $-1,67$ & 1,80 & 2,00 & 1,33 \\
5 & 0,00 & 0,14 & $-0,80$ & $-2,00$ & 0,14 & $-0,80$ & $-2,00$ \\
$\begin{array}{c}\text { Rata-Rata } \\
\text { Indeks }\end{array}$ & $-1,50$ & $-0,60$ & $-1,39$ & $-2,23$ & 1,09 & 0,11 & $-0,73$ \\
Sharpe & & & & & & & \\
\hline
\end{tabular}

Sumber: Data diolah, 2018

Keterangan:

Beda $=$ selisih Indeks Sharpe portofolio winner periode formasi dengan periode kepemilikan selanjutnya

Hasil perhitungan rata-rata kumulatif Indeks Sharpe portofolio saham winner periode formasi 12 bulan dengan periode kepemilikan 3, 6, 12 bulan selanjutnya dapat dilihat pada Tabel 4 sedangkan untuk hasil perhitungan rata-rata kumulatif Indeks Sharpe portofolio saham loser dapat dilihat pada Tabel 5.

Tabel 5.

Rata-Rata Indeks Sharpe Portofolio Loser Periode Formasi 12 Bulan dengan Periode Kepemilikan 3, 6, 12 Bulan Tahun 2009-2014

\begin{tabular}{|c|c|c|c|c|c|c|c|}
\hline \multirow{2}{*}{ Observasi } & \multirow{2}{*}{$\begin{array}{l}\text { Periode } \\
\text { Formasi }\end{array}$} & \multicolumn{3}{|c|}{ Periode Kepemilikan } & \multicolumn{3}{|c|}{ Beda } \\
\hline & & 3 Bulan & 6 Bulan & 12 Bulan & 3 Bulan & 6 Bulan & 12 Bulan \\
\hline 1 & $-6,00$ & $-1,00$ & $-2,50$ & $-3,50$ & 5,00 & 3,50 & 2,50 \\
\hline 2 & $-4,00$ & 0,00 & $-1,00$ & $-2,50$ & 4,00 & 3,00 & 1,50 \\
\hline 3 & $-4,00$ & $-2,20$ & $-2,50$ & $-3,00$ & 1,80 & 1,50 & 1,00 \\
\hline 4 & $-6,00$ & 0,44 & 0,29 & $-0,75$ & 6,44 & 6,29 & 5,25 \\
\hline 5 & $-7,00$ & $-0,60$ & $-1,33$ & $-2,00$ & 6,40 & 5,67 & 5,00 \\
\hline $\begin{array}{l}\text { Rata-Rata } \\
\text { Indeks } \\
\text { Sharpe }\end{array}$ & $-5,40$ & $-0,67$ & $-1,41$ & $-2,35$ & 4,73 & 3,99 & 3,05 \\
\hline
\end{tabular}

Sumber: Data diolah, 2018

Keterangan:

Beda $=$ selisih Indeks Sharpe portofolio loser periode formasi dengan periode kepemilikan selanjutnya 
Hasil dari pengujian kinerja portofolio winner dan kinerja portofolio loser dapat dilihat pada Tabel 6/ dan 7. Tabel 6/ merupakan hasil pengujian kinerja portofolio winner-loser yang diukur dengan menggunakan pengukuran abnormal return, sedangkan Tabel 7. merupakan hasil pengujian kinerja portofolio winnerloser yang diukur dengan Indeks Sharpe

Perbedaan signifikansi antara kinerja portofolio winner-loser pada periode formasi dengan kinerja portofolio winner-loser pada periode kepemilikan selanjutnya dapat dianalisis dengan menggunakan uji beda dua rata-rata.

Pengujian dilakukan pada rata-rata kumulatif abnormal return portofolio winner-loser periode formasi dengan periode kepemilikan selanjutnya, dan Indeks Sharpe portofolio winner-loser periode formasi dengan periode kepemilikan selanjutnya sebagai ukuran dari kineja portofolio winner dan portofolio loser.

Tabel 6. menunjukkan bahwa rata-rata kumulatif abnormal return portofolio winner pada periode formasi dengan periode kepemilikan 3, 6, 12 bulan selanjutnya memiliki perbedaan yang negatif dan tidak signifikan, sedangkan untuk portofolio loser pada periode formasi dengan periode kepemilikan selanjutnya memiliki perbedaan yang positif dan tidak signifikan.

Tabel 7 menunjukkan bahwa rata-rata Indeks Sharpe portofolio winner pada periode formasi dengan periode kepemilikan 3, 6, 12 bulan selanjutnya memiliki perbedaan yang positif serta negatif tidak signifikan, sedangkan pada portofolio loser memiliki perbedaan rata-rata Indeks Sharpe yang positif dan signifikan.

Tabel 6.

Hasil Uji Beda Dua Rata-Rata Abnormal Return Portofolio Winner-Loser pada Periode Formasi 12 Bulan dengan Periode Kepemilikan 3, 6, 12 Bulan Selanjutnya Tahun 2012-2017

\begin{tabular}{cccccc}
\hline \multirow{2}{*}{ No. } & Periode Kepemilikan & \multicolumn{2}{c}{ Winner } & \multicolumn{2}{c}{ Loser } \\
& & Beda & Sig & Beda & Sig \\
\hline 1 & 3 bulan & $-0,02$ & 0,789 & 0,02 & 0,782 \\
2 & 6 bulan & $-0,04$ & 0,613 & 0,02 & 0,782 \\
3 & 12 bulan & $-0,02$ & 0,729 & 0,03 & 0,700 \\
\hline
\end{tabular}

Sumber: Data diolah, 2018

Keterangan:

Beda $=$ selisih abnormal return portofolio winner-loser periode formasi dengan periode kepemilikan selanjutnya.

Berdasarkan hasil uji beda dua rata-rata yang terlihat pada Tabel 6. dan Tabel 7, bahwa tidak terdapat perbedaan yang signifikan antara kinerja portofolio winner pada periode formasi dengan kinerja portofolio winner pada periode kepemilikan selanjutnya, sehingga hasil ini membuat hipotesis 1 ditolak. Hal ini dapat dibuktikan dengan hasil uji beda dua rata-rata abnormal return dan Indeks Sharpe portofolio winner yang tidak signifikan. Sedangkan hasil uji beda dua rata-rata Indeks Sharpe pada portofolio loser mendapatkan hasil yang signifikan, sehingga ini membuat hipotesis 2 diterima. Dari penelitian ini membuktikan bahwa tidak 
terjadinya momentum melainkan adanya strategi kontrarian, dimana strategi kontrarian merupakan strategi yang digunakan investor untuk mengharapkan terjadinya pembalikan terhadap return saham pada jangka waktu tertentu, yaitu tingkat return yang awalnya positif atau negatif diharapkan mengalami pembalikan pada jangka waktu tertentu.

Tabel 7.

Hasil Uji Beda Dua Rata-Rata Indeks Sharpe Portofolio Winner-Loser pada Periode Formasi 12 Bulan dengan Periode Kepemilikan 3, 6, 12 Bulan Selanjutnya Tahun 2012-2017

\begin{tabular}{cccccc}
\hline \multirow{2}{*}{ No. } & Periode Kepemilikan & \multicolumn{3}{c}{ Winner } & \multicolumn{2}{c}{ Loser } \\
& & Beda & Sig & Beda & Sig \\
\hline 1 & 3 bulan & 1.09 & 0,124 & 4,73 & $0,005^{*}$ \\
2 & 6 bulan & 0,11 & 0,873 & 3,99 & $0,011^{*}$ \\
3 & 12 bulan & $-0,73$ & 0,431 & 3,05 & $0,011^{*}$ \\
\hline
\end{tabular}

Sumber: Data diolah, 2018

Keterangan:

Beda $=$ selisih Indeks Sharpe portofolio winner-loser periode formasi dengan periode kepemilikan selanjutnya

\section{SIMPULAN}

Kinerja portofolio saham winner periode formasi dengan periode kepemilikan 3, 6, 12 bulan selanjutnya mendapatkan hasil yang tidak signifikan. Hal ini berarti tidak ada perbedaan signifikan antara kinerja portofolio saham winner pada periode formasi dengan kinerja portofolio saham winner pada periode kepemilikan selanjutnya untuk periode 2012-2017. Hal ini didukung oleh hasil uji beda dua rata-rata kumulatif abnormal return dan Indeks Sharpe portofolio winner yang hasilnya tidak signifikan.

Kinerja portofolio saham loser periode formasi dengan periode kepemilikan $3,6,12$ bulan selanjutnya mendapatkan hasil yang signifikan. Hal ini berarti adanya perbedaan signifikan antara kinerja portofolio saham loser pada periode formasi dengan kinerja portofolio saham loser pada periode kepemilikan selanjutnya. Hal ini didukung oleh hasil uji beda dua rata-rata kumulatif Indeks Sharpe portofolio loser yang menjukkan signifikan untuk periode 2012-2017.

Investor atau manajer investasi diharapkan untuk membeli saham-saham pada kategori winner dan hati-hati untuk membeli saham-saham pada kategori loser periode 2012-2017, karena pada penelitian ini saham-saham pada kategori loser memiliki kinerja menurun yang berkepanjangan selama 12 bulan. Peneliti selanjutnya disarankan untuk melakukan variasi yang berbeda pada sampel penelitiannya, seperti dengan menggunakan segmen industri, misalnya industri manufaktur. 


\section{REFERENSI}

Bildik, R., \& Gulay, G. (2001). Profitability of Contrarian vs. Momentum Strategies: from the Istanbul Stock Exchange. JEL Classification, 12-14.

Chan, L. K. C., Jegadeesh, N., \& Lakonishok, J. (1996). Momentum Strategies. The Journal of Finance, LI(5), 1681-1713. Retrieved from http://wwwstat.wharton.upenn.edu

Darusman, D. (2012). Analisis Pengaruh Firm Size, Book to Market Ratio, Price Earning Ratio, dan Momentum terhadap Return Portofolio Saham. Diponegoro Journal of Management, 1(1), 212-225. Retrieved from http://ejournal-s1.ubndip.ac.id/index.php/djom

Demir, I., Muthuswamy, J., \& Walter, T. (2004). Momentum Returns in Australian Equities: The Influences of Size, Risk, Liquidity and Return Computation. Pasific-Basin Finance Journal, 12, 143-158. https://doi.org/10.1016/j.pacfin.2003.07.002

Douagi, B. M., \& Chaouachi. (2011). What Should We Know About Momentum Strategies? The Case of The Tunisian Stock Market. Journal of Business Studies Quarterly, 3(1), 218-229.

Elias, S. M., Hanis, N. N., Azmi, N., \& Kamil, K. H. (2014). Industry Momentum Strategy in Malaysian Stock Market. International Journal of Business and Social Science, 5(11), 194-202.

Forner, C., \& Marhuenda, J. (2003). Contrarian and Momentum Strategies in the Spanish Stock Market. European Financial Management, 9(1), 67-88.

Grundy, B. D., \& Martin, J. S. (2001). Understanding the Nature of the Risks and the Source of the Rewards to Momentum Investing. Review of Financial Studies, 14(1), 29-78.

Gunarsa, \& Ekayani, S. (2011). Pengujian Eksistensi Anomali Winner-Loser Saham Industri Manufaktur di PT. Bursa Efek Indonesia. Jurnal Ilmiah Manajemen \& Akuntansi STIE Triatma Mulya, 16(2), 33-41.

Hameed, A., \& Kusnasi, Y. (2002). Momentum Strategies: Evidence from Pasific Basin stock markets. Journal of Financial Research, 25(3), 383-397.

Harianto, E. (2008). Analisa Efektivitas Momentum Investment Strategy dalam Menghasilkan Abnormal Return (Studi Kasus pada Semua Saham Perusahaan yang Terdaftar di BEJ).

Hartono, Jogiyanto. (2013). Teori Portofolio dan Analisis Investasi. Edisi Kedelapan. Yogyakarta: BPFE.

Haugen, R.A. (2001). Modern Investment Theory. Fifth Edition. New Jersey: Prentive Hall. 
Henker, J. (2012). The Vanishing Abnormal Returns of Momentum Strategies and 'Front-Running' Momentum Strategies. Journal of Accounting and Finance, 12(4), 86-100.

Hurn, S., \& Pavlov, V. (2003). Momentum in Australian Stock Returns. Australian Journal of Management, 28(2), 141-155. Retrieved from http://citeseerx.ist.psu.edu

Husnan, Suad. (2012). Dasar-dasar Teori Portofolio dan Analisis Sekuritas. Yogyakarta: UPP AMP YKPN.

Indrianto, Nur dan Bambang Supomo. (2009). Metodologi Penelitian Bisnis Untuk Akuntansi dan Manajemen. Edisi Pertama. Yogyakarta: BPFE.

Jegadeesh, N., \& Titman, S. (1993). Returns to Buying Winner and Selling Losses: Implications for Stock Market Efficiency. Journal of Finance, 48(1), 65-91.

Jones, Charles P. (2004). Investment: Analysis and Management, $8^{\text {th }}$ Ed. New York: John Willey \& Sons.

Kartajaya, Hermawan. (2009). Kompas 100 Corporate Marketing Case. Jakarta: PT Gramedia Pustaka Utama.

Mansouri, S., Tehrani, R., \& Ansari, H. (2012). Momentum Returns in Tehran Stock Exchange: The Influence of Size and Liquidity. International Business Research, 5(11), 43-53.

Moskowitz, T. J., \& Grinblatt, M. (2007). Do Industries Explain Momentum? The Journal of Finance, 54(4), 1249-1290. Retrieved from http://links.jstor.org/sici?sici=00221082\%28199908\%2954\%3A4\%3C1249\%3ADIEM\%3E2.0.CO\%3B2-5.

Najmudin. (2009). Eksistensi Profitabilitas Strategi Investasi Momentum di Bursa Efek Indonesia. Performance, 9(2), 1-14.

Pasaribu, R. (2011). ANOMALI OVERREACTION DI BURSA EFEK INDONESIA : Case Study of LQ 45 Stocks. Jurnal Ekonomi Dan Bisnis, 5(2), 87-115. https://doi.org/10.20961/jab.v9i2.101

Rahmawati, \& Suryani, T. (2005). Over Reaksi Pasar terhadap Harga Saham Perusahaan Manufaktur di Bursa Efek Jakarta. SNA VIII, 64-74.

Rahyuda, Ketut. (2016). Metodelogi Penelitian Bisnis Edisi Revisi 2017. Bali: Udayana University Press

Rouwenhorst, K. G. (1998). International Momentum Strategies. The Journal of Finance, 53(1), 267-284.

Samsul, Mohammad. (2006). Pasar Modal dan Manajemen Portofolio. Jakarta: Erlangga.

Saputro, R. N., \& Badjra, I. B. (2016). Kinerja Portofolio Saham berdasarkan 
Strategi Investasi Momentum pada Industri Manufaktur. E-Jurnal Manajemen Unud, 5(1), 623-649.

Sartono, A. (2000). Overreaction of the Indonesia Capital Market: Is Market Rational. Gadjah Mada International of Business, 2(2), 163-184.

Shan-Hu, J. W., \& Chen, Y. C. (2011). The Performance of Momentum Investment Strategies: An International Examination of Stock Markets. International Journal of Management, 28(4), 165-195.

Sharpe, William F., Gordon J. Alexander dan Jeffery V. Bailey. (1995). Investment. New Jersey: Prentice Hall, Inc.

Wiagustini, N. L. P. (2008). Profitabilitas Strategi Investasi Kontrarian di Bursa Efek Indonesia. Jurnal Manajemen Dan Kewirausahaan, 10(2), 105-114. Retrieved from http://jurnalmanajemen.petra.ac.id

Wiksuana, I. G. B. (2009). Kinerja Portofolio Saham Berdasarkan Strategi Investasi Momentum di Pasar Modal Indonesia, 11(1), 73-84. https://doi.org/doi.org/10.9744/jmk.11.1.pp.73-84

Yunita, E. (2012). Analisis Overraction Hypothesis pada Sektor Perusahaan Properti dan Keuangan yang Go Public di Bursa Efek Indonesia. Jurnal Ilmiah Mahasiswa Manajemen, 1(15), 1-7. 